\title{
Study of some biochemical parameters such as (Total serum bilirubin , Serum GOT , Serum GPT , Serum calcium and Serum ferritin) in thalassemia Patients Abbas Muhsin Gatta (MSc) ${ }^{1}$ and Mahmood Abdullah Qader (MSc) ${ }^{2}$
}

\begin{abstract}
Background: Thalassemia is a major health problem in developing and developed countries and suffers from many children of school age.

Objective:Study of some chemical parameters such as serum bilirubin and some liver enzymes such as GOT, GPT as well as calcium and ferritin in patients with thalassemia.

Patients and Methods: Analysis was performed on 109 patients with thalassemia in the thalassemia unit at Ibn al-Baladi Hospital for Women and Children in Baghdad Governorate. By spectrophotometer (Total serum bilirubin, GOT, GPT, serum calcium, hemoglobin) and vides device for serum fretin.

Results:Showed changes in thalassemia patients with an increase in bilirubin causing hyperbilirubinemia, an increase in GOT and GPT, decreased serum calcium levels in some thalassemia patients, and reduced hemoglobin density and reduced cell size, as well as increased serum ferrite in patients with thalassemia due to frequent blood transfusion.

Conclusion: This study shows an increase in blood vessels in all ages in both sexes due to the breakdown of red blood cells and the repeated blood transfusion, which causes the accumulation of iron in the body and the increase of enzymes and liver secretions (GOT, GPT) due to hepatic hypertrophy as well as increased bilirubin and calcium deficiency in serum thalassemia patients.
\end{abstract}

Key words: Thalassemia, Liver enzymes, Ferritin and Calcium.

Corresponding Author: gatr722@gmail.com

Received: $27^{\text {th }}$ March 2018

Accepted: $24^{\text {th }}$ June 2018

https://doi.org/10.26505/DJM

College of Health and Medical Technology-Baghdad -Iraq.

${ }^{2}$ Al-Mansur Medical Technical Institute - Baghdad-Iraq.

\section{Introduction}

Is a general name for a group of inherited blood diseases that involve abnormalities in hemoglobin, the oxygen-carrying part of the red blood cells. Hemoglobin is mainly made up of two kinds of protein, called alpha and beta globin[1,2,3]. Individuals with thalassemia do not produce enough of one (or occasionally both) of these proteins. As a result, their red blood cells may be abnormal and unable to carry enough oxygen throughout the body [4]. The two main types of thalassemia are called alpha and beta thalassemia:-

1-Individuals with alpha thalassemia do not produce enough alpha globin.

2-Those with beta thalassemia do not produce enough beta globin [4].

There are a number of different forms of alpha and beta thalassemia's, with symptoms ranging from mild to severe [5]. 
Study of some biochemical parameters such as (Total serum bilirubin, Serum GOT, Serum GPT ,

Serum calcium and Serum ferritin) in thalassemia Patients

Thalassemia is among the most common inherited disorders caused by a single abnormal gene [6,7], more than 100,000 babies worldwide are born each year with severe forms of thalassemia[8,9] , according to the national academy of sciences , thalassemia occurs most frequently in people of Italia ,Greek , Middle east, southern Asian and African ancestry [10]. Iraqi children with thalassemia have demonstrated a higher rate than that reported in other countries , such as Jordan, Saudia Arabia, turkey, Taiwan, and India according to study done on 559 thalassaemic children from ibn Albalady teaching hospital -Baghdad, during 1998 [11].

Complications due to thalassemia[12].

1-Transmission of viral hepatitis.

2-Enlarged spleen (hypersplenism).

3-Heart Disease complications.

4-Hepatic complications.

5-Hematologic complications.
6-Hormone system or endocrine complications.

7-Bone complications.

To study some biochemical parameters such as Serum total bilirubin ,Serum GOT , Serum GPT , Serum calcium and Serum ferritin, in patient who have thalassemia disease .

\section{Patients and Methods}

One hundred and nine Patients (69 male, 40 female ) thalassemia major \& thalassemia intermediate were taken, receiving multiple blood transfusions .Apparently healthy donors (31), (17 Males and 14 females) were included in this study to investigate the Biochemical Parameters. The study was done in IbnAl-Balady Hospital in the period from October 2012 to May 2013 .Data recorded included age, gender, GOT, GPT, TSB, S. calcium, and S. ferritin.

\section{Results}

Table (1): Distribution of thalassemia patients according to gender group.

\begin{tabular}{|c|c|c|c|c|c|}
\hline & \multicolumn{2}{|c|}{ Gender } & \multirow[b]{2}{*}{ Total } & \multirow[b]{2}{*}{ Pearson Chi-Square } \\
\hline & & Male & female & & \\
\hline \multirow[t]{3}{*}{ Thalassemia Patient } & No. & 69 & 40 & 109 & \\
\hline & $\%$ & $63.3 \%$ & $36.7 \%$ & $100.0 \%$ & \multirow[t]{4}{*}{ P-Value 0.393 N.S, } \\
\hline & No. & 17 & 14 & 31 & \\
\hline Healthy & $\%$ & $54.8 \%$ & $45.2 \%$ & $100.0 \%$ & \\
\hline \multirow[t]{2}{*}{ Total } & No. & 86 & 54 & 140 & \\
\hline & $\%$ & $61.4 \%$ & $38.6 \%$ & $100.0 \%$ & \\
\hline
\end{tabular}

Table (2): Distribution of thalassemia Patients, according to age group (years).

\begin{tabular}{|c|c|c|c|c|c|c|c|}
\hline \multirow{2}{*}{$\begin{array}{c}\text { Age } \\
\text { groups } \\
\text { (years) }\end{array}$} & \multicolumn{2}{|c|}{ Thalaseemia } & \multicolumn{2}{|c|}{ Healthy } & \multicolumn{2}{|c|}{ Total } & Pearson Chi \\
\hline & No. & $\%$ & No. & $\%$ & No. & $\%$ & \multirow{6}{*}{$\begin{array}{c}\text { p. value } \\
0.03 \\
\text { S }\end{array}$} \\
\hline $1-10$ & 42 & 38.5 & $\overline{6}$ & 19.4 & 48 & 34.3 & \\
\hline $11-20$ & 40 & 36.7 & 10 & 32.3 & 50 & 35.7 & \\
\hline $21-30$ & 19 & 17.4 & 7 & 22.6 & 26 & 18.6 & \\
\hline$\geq 31$ & 8 & 7.4 & 8 & 25.8 & 16 & 11.5 & \\
\hline Total & 109 & 100 & 31 & 100 & 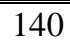 & 100 & \\
\hline
\end{tabular}


Study of some biochemical parameters such as (Total serum bilirubin, Serum GOT, Serum GPT ,

Table (3): Distribution of thalassemia Patients, according to GOT.

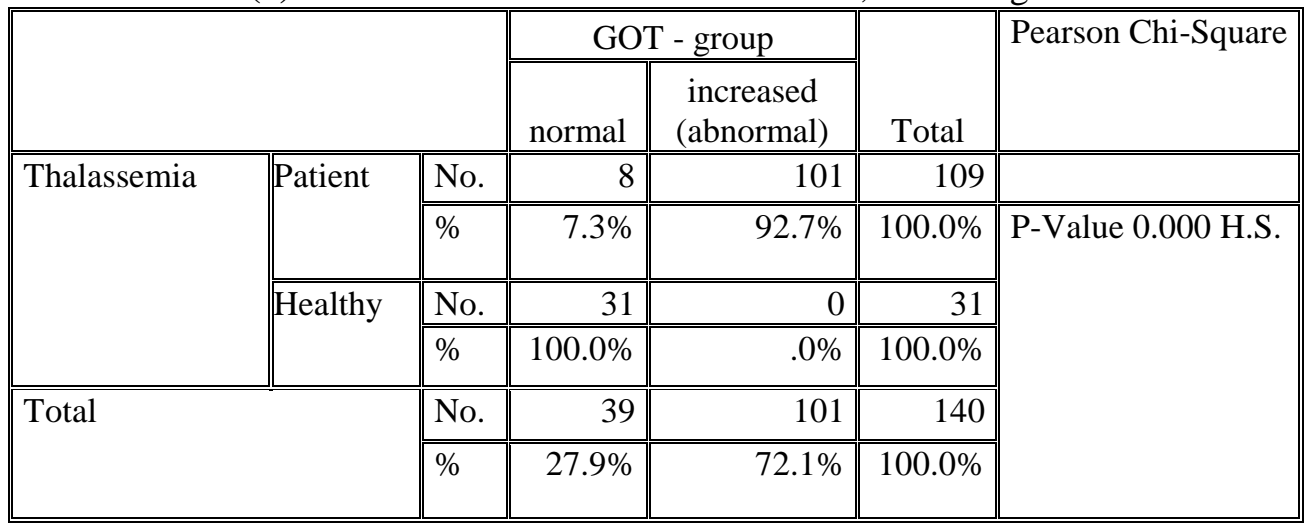

Table (4): Distribution of thalassemia Patients, according to GPT.

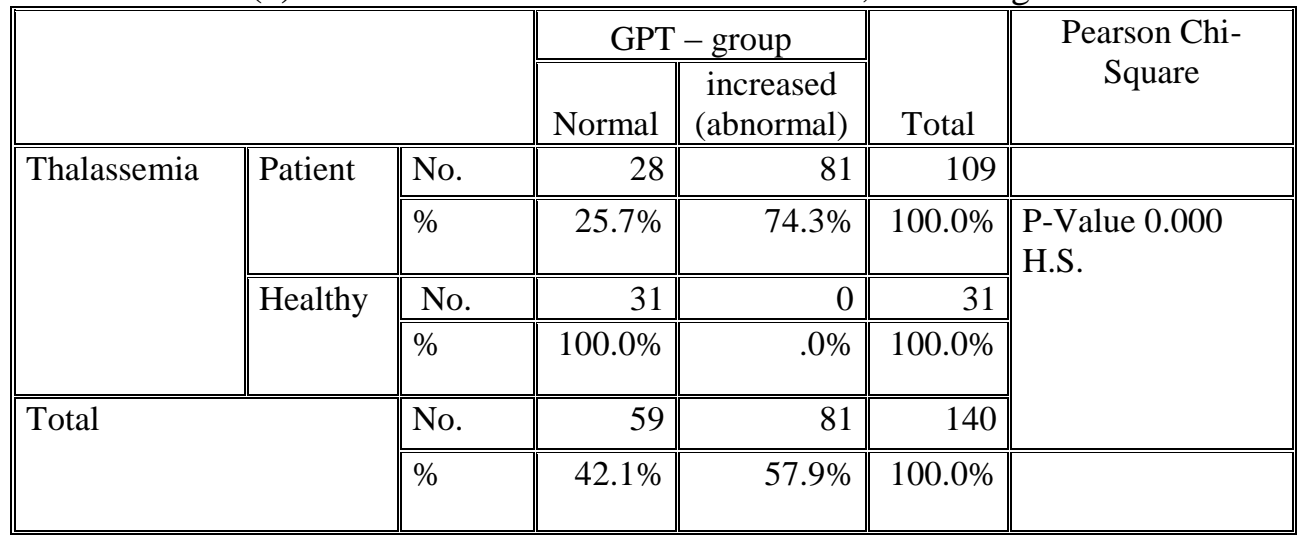

Table (5): Distribution of thalassemia Patients, according to STB ( serum total bilirubin ).

\begin{tabular}{|c|c|c|c|c|c|c|}
\hline & \multicolumn{2}{|c|}{ S.T.B - group } & \multirow[b]{2}{*}{ Total } & \multirow[t]{2}{*}{ Pearson Chi-Square } \\
\hline & & & $\begin{array}{c}\text { norma } \\
1\end{array}$ & $\begin{array}{c}\text { increased } \\
\text { (abnormal) }\end{array}$ & & \\
\hline \multirow[t]{4}{*}{ Thalassemia } & \multirow[t]{2}{*}{ Patient } & No. & 43 & $\overline{666}$ & 109 & \\
\hline & & $\%$ & $39.4 \%$ & $60.6 \%$ & $100.0 \%$ & \multirow[t]{4}{*}{ P-Value 0.000 H.S. } \\
\hline & \multirow[t]{2}{*}{ Healthy } & No. & 29 & 1 & 30 & \\
\hline & & $\%$ & $96.7 \%$ & $3.3 \%$ & $100.0 \%$ & \\
\hline \multirow{2}{*}{\multicolumn{2}{|c|}{ Total }} & No. & $\overline{72}$ & 67 & 139 & \\
\hline & & $\%$ & $51.8 \%$ & $48.2 \%$ & $100.0 \%$ & \\
\hline
\end{tabular}


Study of some biochemical parameters such as (Total serum bilirubin, Serum GOT, Serum GPT ,

Serum calcium and Serum ferritin) in thalassemia Patients

Table (6): Distribution of thalassemia Patients, according to S.calcium.

\begin{tabular}{|c|c|c|c|c|c|c|c|}
\hline & \multicolumn{3}{|c|}{ S. calcium - group } & \multirow[b]{2}{*}{ Total } & \multirow{2}{*}{$\begin{array}{c}\text { Pearson } \\
\text { Chi-Square }\end{array}$} \\
\hline & & & $\begin{array}{l}\text { Decreased(a } \\
\text { bnormal) }\end{array}$ & Normal & $\begin{array}{c}\text { increased } \\
\text { (abnormal) }\end{array}$ & & \\
\hline \multirow[t]{4}{*}{ Thalassemia } & \multirow[t]{2}{*}{ Patient } & No. & 48 & 55 & 6 & 109 & \multirow{5}{*}{$\begin{array}{l}\text { P-Value } \\
0.001 \text { H.S. }\end{array}$} \\
\hline & & $\%$ & $44.0 \%$ & $50.5 \%$ & $5.5 \%$ & $100.0 \%$ & \\
\hline & \multirow[t]{2}{*}{ Healthy } & No. & 4 & 27 & 0 & 31 & \\
\hline & & $\%$ & $12.9 \%$ & $87.1 \%$ & $.0 \%$ & $100.0 \%$ & \\
\hline \multirow{2}{*}{\multicolumn{2}{|c|}{ Total }} & No. & 52 & 82 & $\overline{66}$ & 140 & \\
\hline & & $\%$ & $37.1 \%$ & $58.6 \%$ & $4.3 \%$ & $100.0 \%$ & \\
\hline
\end{tabular}

Table (7): Distribution of thalassemia Patients, according to S. ferritin.

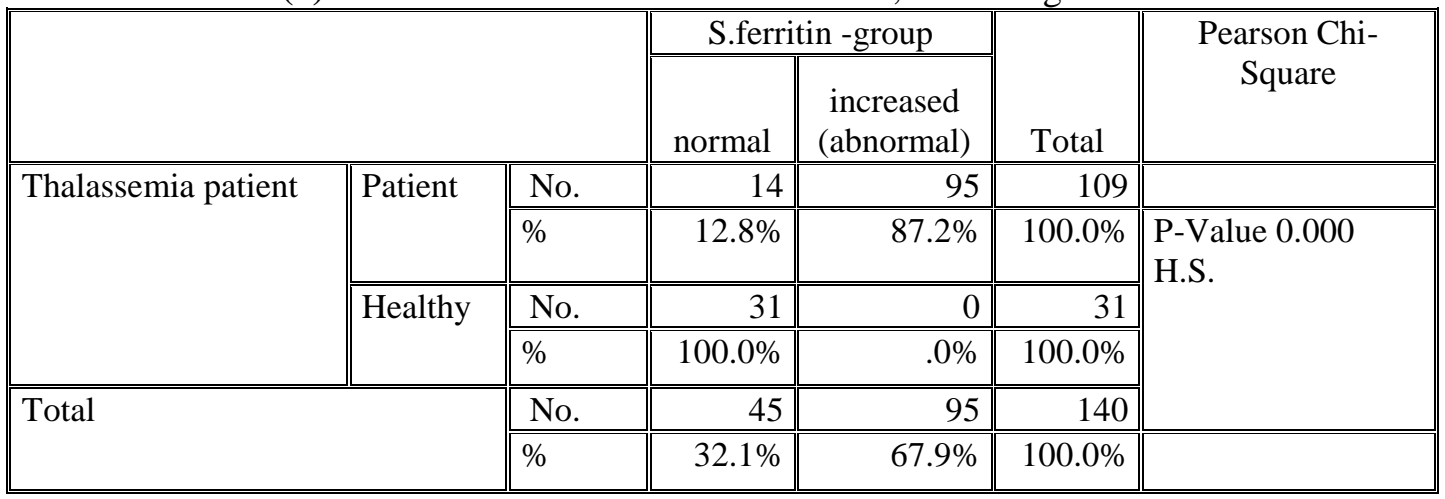

\section{Discussion}

A Total of (140): thalassemia patient (109 , 77.8\%), and apparently healthy control (31 , 22.2\%) Were included in the present study. Data from table (1) show, that the number of male $(69,63.3 \%)$ and female $(40,36.7 \%)$, with male to female ratio which were afflicted with thalassemia disease, compared with a male $(17,54.8 \%)$ and female (14 ,45.2\%) which were apparently healthy control. The Result of gender in this study which obtained from collection, noted that there was non-significant differences between male and female (gender).P. value $(<0.393)$ and this results disagree with previous study which reported that there was no differences between male and female thalassemia patients[13].

Data From Table (2) indicate that the number and percentage (No.\&\%) of patients afflicted with thalassemia disease Were higher at age group (1-10 years) No 42 and (11-20years) No 40 than other groups (21-30 years) No 19 and (31-40 years) No 6 with significant between age groups $(\mathrm{P}<0.037$ ) comparison with age groups of apparently health control. The above result agreed with numerous studies which showed that thalassemia patients are associated with 
Study of some biochemical parameters such as (Total serum bilirubin, Serum GOT, Serum GPT ,

Serum calcium and Serum ferritin) in thalassemia Patients

younger ages. and these cases usually diagnosed in middle ages [14]. The results in Table (3) revealed that there were (101, $92.7 \%)$ Patients with thalassemia in comparison with $(31,100 \%)$, apparently healthy control respectively, that there was a highly significant rise in the mean concentration of serum GOT Level in the sera of thalassemia patients group in comparison with the mean Concentration of apparently healthy control group was highly significant differences $(\mathrm{P}<0.01)$.

The results in table (4) showed that there were $(81,74.3 \%)$. Patients afflicted with thalassemia in comparison with $(31,100 \%)$, apparently healthy control respectively, that there was a highly significant rise in the mean concentration of serum GPT Level in the sera of thalassemia patients group in comparison with the mean Concentration of apparently healthy control group, With highly significant differences $(\mathrm{P}<0.01)$. The results in Table(5) show that there were (66 ,80.6\%) Patients afflicted with thalassemia in comparison with $(30,96.7 \%)$, apparently healthy control respectively, that there was a highly significant rise in the mean concentration of serum STB Level in the sera of thalassemia patients group Comparison with the mean Concentration of apparently healthy control group. With highly significant differences $(\mathrm{P}<0.01)$.

The results in Table (6) that there were (55, 50.5\%) Patients afflicted with thalassemia in comparison with $(31,100 \%)$, apparently healthy control, that there was a highly significant Normal and about (48,
44\%) patients decreased in the mean concentration of serum calcium Level in the sera of thalassemia patients group in comparison with the mean Concentration of apparently healthy control group With highly significant differences $(\mathrm{P}<0.01)$.

Table (7) showed that there were (95, $87.2 \%)$ Patients suffering from thalassemia in comparison with (31), apparently healthy control, that there was a highly significant rise in the mean concentration of serum Ferritin Level in the sera of thalassemia patients group in comparison with the mean Concentration of apparently healthy control group with highly significant differences ( $\mathrm{P}<0.01)$.

\section{Conclusions}

1-After analyzing patients we found that the serum ferritin is increase at all ages and sex (Female and male) because there is destruction of RBC and blood transfusion then accumulation of iron in the body .

2-Serum calcium show decrease or normal in patients with Thalassemia .

3-Serum GOT \& GPT show high because of hyperhepatomegaly .

4-Serum bilirubin will show hyperbilirubinemia always almost in Thalassemia patients.

\section{Recommendations}

1-Avoiding marriage of relatives because this disease is hereditary .

2-Iron medications and iron rich foods should be not be given (avoided) due to blood transfusion frequently .

3-Normal diet is recommended with attention with following supplements : folic 
Study of some biochemical parameters such as (Total serum bilirubin, Serum GOT, Serum GPT ,

Serum calcium and Serum ferritin) in thalassemia Patients

acid , ascorbic acid (vitamin C) and alphatocopherol (vitamin E) .

\section{References}

[1]Stefano R. In effeective erythropoiesis and thalassemias. Curr Opinion Hematol. (2009);16:187-94.

[2] 2. Cappellini MD, Cohen A, Eleftheriou A, Piga A, Porter J, Taher A, TIF guidelines for clinical management of thalassemia 2nd ed Nicosia Cyprus : Thalassemia international federation Nicosia Cyprus;(2008):21-35.

[3]Lukens JN. Thalassemia Major. In: NORD Guide to Rare Disorders. Lippincott Williams \& Wilkins. Philadelphia, PA(2003)::419.

[4] Galanello R, Origa R, Beta - thalassemia. Orphanet J Rare Dis. (2010) ;5:11-8.

[5]Rund, D. and Rachmilewitz, E. Medical Progress: Beta-Thalassemia. New England Journal of Medicine, (2005) volume 353, number 11, pages 1135-1146.

[6]Alain J. Marengo-Rowe. The thalassemias and related disorders: (2007): 20(1): 27-31.

[7]Zeinalian M, Samavat A, FadayeeNobari $\mathrm{R}$, Azin S.; Incidence rate of major betathalassemia and study of its causes after prevention and control program of thalassemia in Isfahan province. Sci J Iran Blood Transfuse Organ. ( 2010);6(4):238-47. [8]Jamison DT, Breman JG, Measham AR, et al., editors. Washington (DC) (2006).: The International Bank for Reconstruction and Development / The World Bank; New York. [9] Cao A, Galanello R, Beta -thalassemia .genetics med. (2010);12:61-67.
[10]Fung EB, Harmatz PR, Lee PD, et al.; Increased prevalence of iron over load associated endocrinopathy in thalassemia versus sickle cell disease . Be J Haematol; (2006)135(4):574-82.Medline.

[11] Prabhu R, Prabhu V, Prabhu RS. Iron overload in beta- thalassemia . A review . J Biosci Tech.(2009);1:20-31. [12]Borgna-Pignatti C, Gamberini MR. Expert Rev Hematol; (2011) 4(3):353-66. Complications of thalassemia major and their treatment.

[13]Maria Marsella, CaterinaBorgnaPignatti, AntonellaMeloni, Valeria Caldarelli, Maria Chiara Dell'Amico,Anna Spasiano, LorellaPitrolo, ElianaCracolici, GianlucaValeri, Vincenzo Positano, Massimo Lombardi, and AlessiaPepe ; Haematologica: Cardiac iron and cardiac disease in males and females with transfusion-dependent thalassemia major: a T2* magnetic resonance imaging study. ( 2011) 96(4): 515-520.

[14] Palit S, Bhuiyan RH, Aklima J, Emran TB, Dash R:A study of the prevalence of thalassemia and its correlation with liver function test in different age and sex group in the Chittagong district of Bangladesh. J Basic Clin Pharma(2012);3:352-7. 